\title{
High-yield production of L-serine
} through a novel identified exporter combined with synthetic pathway in Corynebacterium glutamicum

\author{
Xiaomei Zhang ${ }^{1}$, Yujie Gao ${ }^{1}$, Ziwei Chen ${ }^{1}$, Guoqiang Xu' ${ }^{2,3}$, Xiaojuan Zhang ${ }^{2,3}$, Hui Li ${ }^{1}$, Jinsong Shi ${ }^{1}$, \\ Mattheos A. G. Koffas ${ }^{4,5^{*}}$ (iD and Zhenghong $\mathrm{Xu}^{2,3^{*}}$
}

\begin{abstract}
Background: L-Serine has wide and increasing applications in industries with fast-growing market demand. Although strategies for achieving and improving L-serine production in Corynebacterium glutamicum (C. glutamicum) have focused on inhibiting its degradation and enhancing its biosynthetic pathway, L-serine yield has remained relatively low. Exporters play an essential role in the fermentative production of amino acids. To achieve higher L-serine yield, L-serine export from the cell should be improved. In C. glutamicum, ThrE, which can export L-threonine and L-serine, is the only identified L-serine exporter so far.

Results: In this study, a novel L-serine exporter NCgl0580 was identified and characterized in C. glutamicum $\triangle$ SSAAI (SSAAI), and named as SerE (encoded by serE). Deletion of serE in SSAAI led to a 56.5\% decrease in L-serine titer, whereas overexpression of serE compensated for the lack of serE with respect to L-serine titer. A fusion protein with SerE and enhanced green fluorescent protein (EGFP) was constructed to confirm that SerE localized at the plasma membrane. The function of SerE was studied by peptide feeding approaches, and the results showed that SerE is a novel exporter for L-serine and L-threonine in C. glutamicum. Subsequently, the interaction of a known L-serine exporter ThrE and SerE was studied, and the results suggested that SerE is more important than ThrE in L-serine export in SSAAI. In addition, probe plasmid and electrophoretic mobility shift assays (EMSA) revealed NCgl0581 as the transcriptional regulator of SerE. Comparative transcriptomics between SSAAI and the NCgI0581 deletion strain showed that NCgl0581 is a positive regulator of NCgI0580. Finally, by overexpressing the novel exporter SerE, combined with L-serine synthetic pathway key enzyme serA $\triangle 197$, serC, and serB, the resulting strain presented an L-serine titer of $43.9 \mathrm{~g} / \mathrm{L}$ with a yield of $0.44 \mathrm{~g} / \mathrm{g}$ sucrose, which is the highest L-serine titer and yield reported so far in C. glutamicum.
\end{abstract}

Conclusions: This study provides a novel target for L-serine and L-threonine export engineering as well as a new global transcriptional regulator NCgl0581 in C. glutamicum.

Keywords: L-Serine, Exporter, C. glutamicum, Transcriptional regulator, Metabolic engineering

*Correspondence: koffam@rpi.edu; zhenghxu@jiangnan.edu.cn

${ }^{3}$ The Key Laboratory of Industrial Biotechnology, Ministry of Education,

School of Biotechnology, Jiangnan University, Wuxi, People's Republic of China

${ }^{5}$ Department of Biological Sciences, Rensselaer Polytechnic Institute, Troy, NY, USA

Full list of author information is available at the end of the article

\section{Background}

L-Serine has been identified as one of the top 30 most interesting building blocks for a range of chemicals and materials, and is used in cosmetic, pharmaceutical, and food industries $[1,2]$. Metabolic engineering of C. glutamicum for $\mathrm{L}$-serine production has been focused on

(c) The Author(s) 2020. This article is licensed under a Creative Commons Attribution 4.0 International License, which permits use, sharing, adaptation, distribution and reproduction in any medium or format, as long as you give appropriate credit to the original author(s) and the source, provide a link to the Creative Commons licence, and indicate if changes were made. The images or other third party material in this article are included in the article's Creative Commons licence, unless indicated otherwise in a credit line to the material. If material is not included in the article's Creative Commons licence and your intended use is not permitted by statutory regulation or exceeds the permitted use, you will need to obtain permission directly from the copyright holder. To view a copy of this licence, visit http://creativeco mmons.org/licenses/by/4.0/. The Creative Commons Public Domain Dedication waiver (http://creativecommons.org/publicdomain/ zero/1.0/) applies to the data made available in this article, unless otherwise stated in a credit line to the data. 
its terminal synthesis pathways and degradation pathways, and proven to be very useful for improving L-serine production in this bacterium [3-6]; however, the L-serine productivity achieved is still low for large-scale $\mathrm{L}$-serine production, and the highest reported L-serine titer is 42.62 and $50 \mathrm{~g} / \mathrm{L}$ with an yield of $0.21 \mathrm{~g} / \mathrm{g}$ sucrose and $0.36 \mathrm{~g} / \mathrm{g}$ glucose in C. glutamicum and Escherichia coli (E. coli), respectively. Besides, L-serine can also be potentially produced from sugar via fermentation with a very high theoretical yield $(1.17 \mathrm{~g} / \mathrm{g}$ glucose, $1.22 \mathrm{~g} / \mathrm{g}$ sucrose) [2].

For enhancing L-serine production, an improvement in L-serine export from the cell should be considered. Export system plays an essential role in metabolic engineering strategies for the production of amino acids [7], because it reduces intracellular amino acid concentrations, thereby alleviating feedback inhibition and circumventing toxicity problems $[1,8-10]$. In recent decades, several export systems have been identified for excreting amino acids, such as L-lysine, L-cysteine, L-glutamate, L-threonine, L-arginine, L-methionine, and branched-chain amino acids, in C. glutamicum and E. coli [11-17]. However, to the best of our knowledge, except for ThrE (L-threonine and L-serine exporter) [15, 18], no other L-serine exporters have been reported in C. glutamicum so far. In E. coli, Mundhada et al. found that intracellular $\mathrm{L}$-serine accumulation was toxic to the engineered strain modified to produce L-serine, and that following overexpression of eamA, which encodes L-cysteine exporter in E. coli, the engineered strain exhibited increased tolerance toward L-serine with higher L-serine productivity [2]. Therefore, L-serine exporter in C. glutamicum could be a potential target for strain optimization to further improve L-serine production.

It has been reported that homologs similar to the exporters in E. coli might fulfil a comparable function in C. glutamicum [17, 19, 20]. Accordingly, we hypothesized that the homolog to $\operatorname{EamA}(\mathrm{L}$-serine exporter in $E$. coli) might be involved in L-serine export in $C$. glutamicum. In the present study, three homologs to EamA, namely, NCgl2050, NCgl2065, and NCgl0580, were determined, and their functions were identified by targeted gene deletion, respectively. The results showed that one of the genes, NCgl0580 gene, was involved in L-serine export. Subsequently, localization and function of NCgl0580 were investigated, and the interaction of a known L-serine exporter ThrE (encoded by $t h r E$ ) and the novel exporter NCgl0580 was studied. Furthermore, the transcriptional regulator of $\mathrm{NCgl0580}$ was identified and studied. Finally, the effects of overexpression of L-serine exporter in combination with L-serine synthetic pathway enzyme on L-serine production were evaluated.

\section{Results}

Exploring putative L-serine exporters in C. glutamicum

In previous studies, homologs of $E$. coli exporters have been shown to have similar functions in C. glutamicum $[17,19,20]$. Therefore, we hypothesized that the C. glutamicum homolog to EamA(L-serine exporter in E. coli) [2] might be involved in L-serine export in C. glutamicum. According to the NCBI database, EamA belongs to the RhaT superfamily, and 15 records of related proteins associated with RhaT superfamily in C. glutamicum ATCC13032 were obtained. After eliminating duplicate records, three related genes, NCgl2050, NCgl2065, and NCgl0580 genes, were obtained, which might be involved in L-serine export in C. glutamicum.

To verify the function of these putative proteins in C. glutamicum SSAAI (SSAAI), NCgl2050, NCgl2065, and $\mathrm{NCgl0580}$ were deleted in this strain respectively. The results showed that the deletion of NCgl2050 and NCgl2065 did not produce any changes in cell growth and L-serine titer (Fig. 1a, b). Strikingly, deletion of NCgl0580 significantly reduced the L-serine titer in SSAAI, but did not affect the growth of the strain (Fig. 1c). SSAAI $\triangle \mathrm{NCgl0580}$ produced $11.31 \mathrm{~g} / \mathrm{L}$ L-serine, which was $56.5 \%(\mathrm{p}<0.001)$ lower than that noted in SSAAI (Fig. 1c). However, plasmid-borne overexpression of NCgl0580 compensated for the lack of NCgl0580 with respect to L-serine titer, resulting in $26.76 \mathrm{~g} / \mathrm{L} \mathrm{L}$-serine titer, similar to that generated by the parent strain SSAAI (Fig. 1d). As shown in Fig. 1d, e, when compared with SSAAI, the strain harboring the plasmid grew slowly to some extent in the logarithmic growth phase, finally reaching cell growth similar to that of SSAAI. This finding suggested that $\mathrm{NCgl0580} \mathrm{might} \mathrm{act} \mathrm{as} \mathrm{the} \mathrm{L-serine}$ exporter in C. glutamicum, and was named as SerE and its function was further investigated.

\section{Localization and function of SerE}

According to the NCBI, SerE was presumed to be a hypothetical membrane protein of 301 amino acids, similar to permease of the drug/metabolite transporter (DMT) superfamily. The transmembrane helices of SerE were predicted by TMHMM Server v. 2.0, and SerE exhibited ten transmembrane-spanning helices with both aminoand carboxy-terminal ends in the cytoplasm.

To confirm the localization of SerE, SerE-EGFP fusion protein was expressed in SSAAI. Confocal microscopic observations of SSAAI-egfp and SSAAI-serE-egfp confirmed that EGFP and SerE-EGFP fusion proteins were successfully expressed, respectively (Additional file 1: Fig. S1). To further verify the localization of SerE, membrane and cytoplasmic proteins from these two strains were extracted by ultrasonication, and the fluorescence of these proteins was determined using a fluorescence 

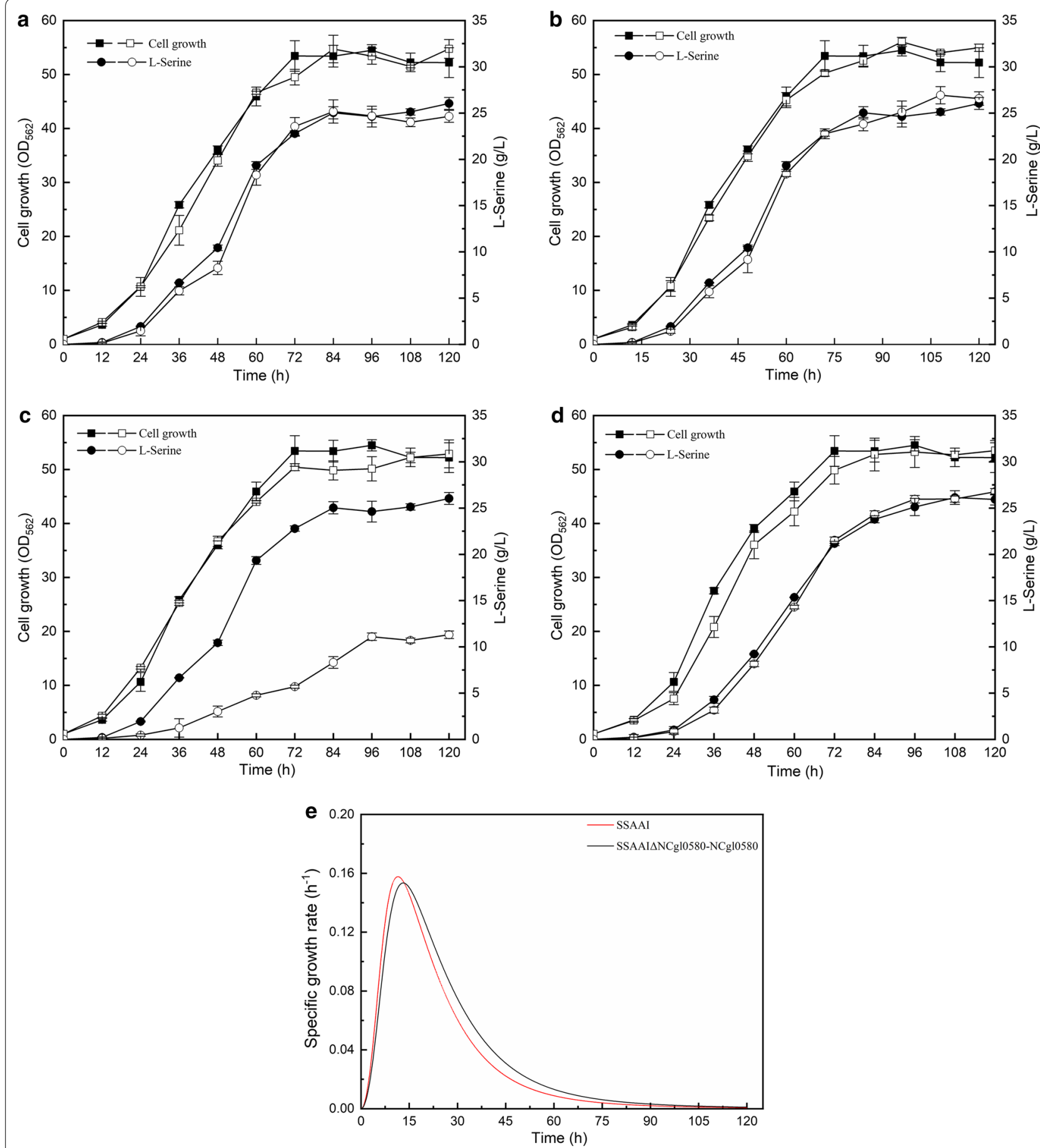

Fig. 1 Effect of NCgl2050, NCgl2065, and NCgl0580 deletion and NCgl0580 complement on SSAAI. (a) Cell growth (squares) and L-serine titer (circles) of NCgl2050 deletion strain SSAAI $N$ NCgl2050 (open symbols) and SSAAI (solid symbols). b Cell growth (squares) and L-serine titer (circles) of NCgl2065 deletion strain SSAAI $\triangle$ NCgl2065 (open symbols) and SSAAI (solid symbols). c Cell growth (squares) and L-serine titer (circles) of NCgI0580

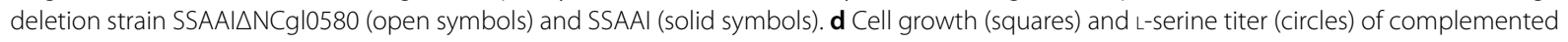

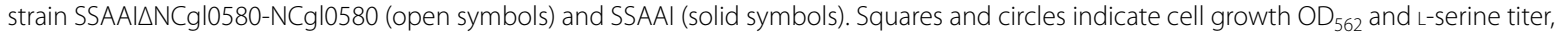
respectively. e The growth rates of the complemented strain SSAAI $\triangle$ N0580-NCgI0580 (red) and SSAAI (black) 
spectrophotometer. The fluorescence of the cytoplasmic proteins of SSAAI-egfp and membrane proteins of SSAAI-serE-egfp (Fig. 2a) affirmed that SerE was localized at the plasma membrane in SSAAI.

To substantiate the function of SerE, a peptide feeding approach was employed by incubating SSAAI and SerE deletion strain, SSAAI $\triangle s e r E$, with $2 \mathrm{mM}$ of the dipeptide Ser-Ser, respectively, and measuring the concentration of extracellular L-serine. As shown in Fig. 2b, a higher L-serine concentration was detected in SSAAI, when compared with that in SSAAI $\Delta s e r E$, confirming that SerE is a novel exporter of L-serine in C. glutamicum.
It is known that L-cysteine export system in $E$. coli (encoded by eamA) also catalyzes L-serine export [2], and that L-threonine exporter in C. glutamicum (encoded by $t h r E$ ) also transports L-serine [15]. We therefore analyzed whether the novel exporter SerE could export L-cysteine or L-threonine. The export experiments with dipeptides (Thr-Thr, Cys-Cys) were performed using SSAAI and SSAAI $\triangle$ serE. The dipeptides were added at a concentration of $2 \mathrm{mM}$ to the medium, and the extracellular amino acid concentrations at different time intervals were determined by HPLC. The results revealed that the concentration of $\mathrm{L}$-cysteine was comparable in both strains and did
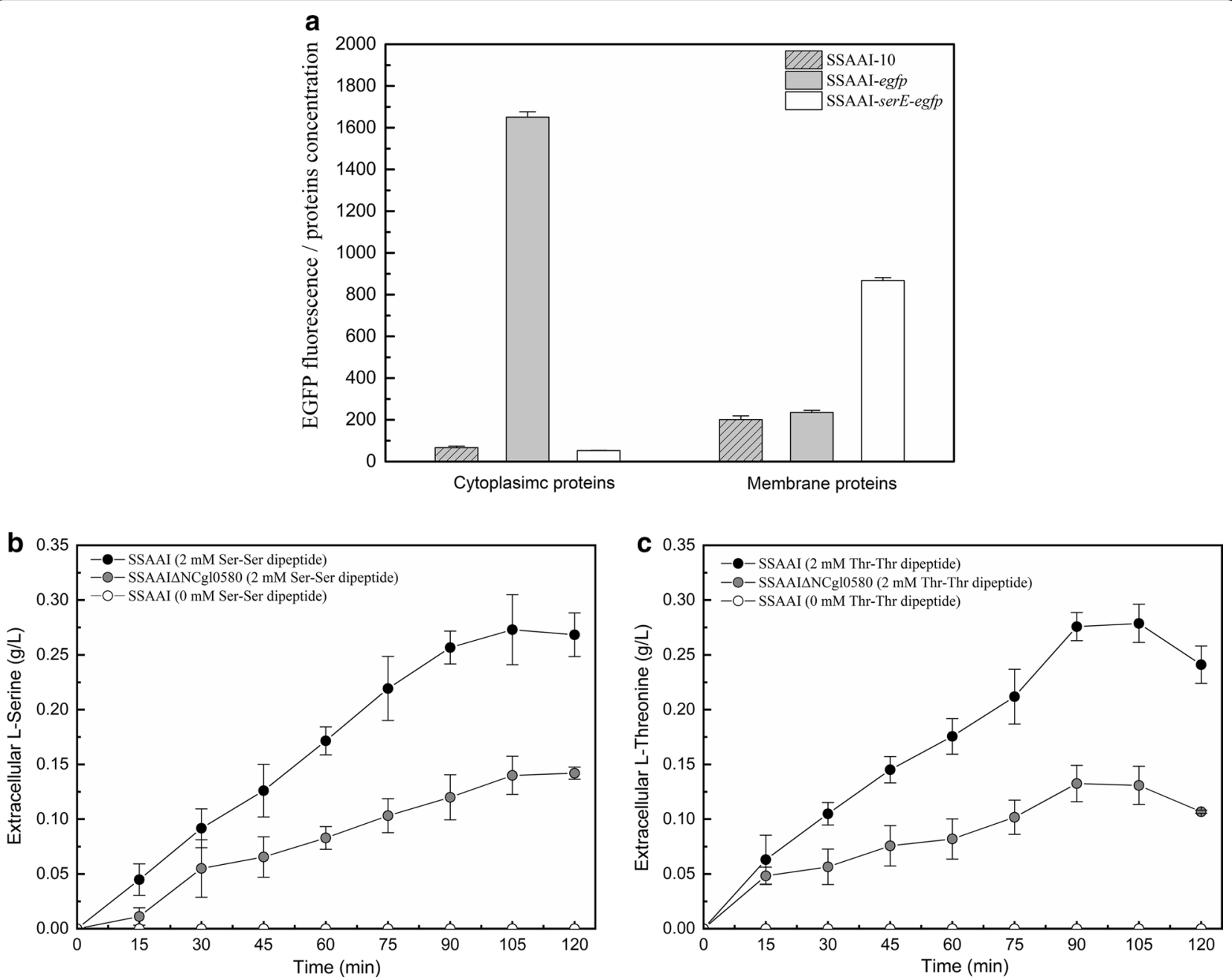

Fig. 2 Fluorescence of cytoplasmic proteins and membrane proteins, and the result of amino acid export of SerE by using peptide feeding approach in SSAAI. a Fluorescence of cytoplasmic proteins and membrane proteins of SSAAI-10 (SSAAl harboring plasmid pDXW-10 only, gray bar with slash), SSAAI-egfp (SSAAI overexpressing EGFP protein with pDXW-10, gray bar), and SSAAI-serE-egfp (SSAAl overexpressing SerE-EGFP fusion protein with pDXW-10, white bar). b Extracellular concentration of L-serine in SSAAI (black circles) and serE deletion strain SSAAI $\triangle$ serE (gray circles) with $2 \mathrm{mM}$ of the dipeptide Ser-Ser. Extracellular concentration of L-serine in SSAAI (white circles) without the dipeptide Ser-Ser. c Extracellular concentration of L-threonine in SSAAI (black circles) and serE deletion strain SSAAI $\triangle$ serE (gray circles) with $2 \mathrm{mM}$ of the dipeptide Thr-Thr. Extracellular concentration of L-threonine in SSAAI (white circles) without the dipeptide Thr-Thr 
not significantly change (data not shown), indicating that SerE might not export L-cysteine. Interestingly, the concentrations of L-threonine in SSAAI $\Delta s e r E$ were lower than those in SSAAI (Fig. 2c), indicating that SerE might be also an exporter of L-threonine in C. glutamicum.

\section{Interaction of a known exporter ThrE and a novel exporter SerE}

It is well known that thrE encodes ThrE that can export L-threonine and L-serine in C. glutamicum ATCC13032 [15]. To understand the interaction between ThrE and SerE on L-serine export, thrE was deleted in SSAAI (SSAAI $\Delta t h r E$ ), which did not produce any significant change in $\mathrm{L}$-serine titer in the deletion mutant (Fig. 3a, b). In contrast, deletion of SerE significantly reduced the $\mathrm{L}$-serine titer in SSAAI, and resulted in little change in cell growth (Fig. 1c). The SSAAI $\Delta s e r E$ produced $11.31 \mathrm{~g} / \mathrm{L}$
L-serine, which was $56.5 \%(\mathrm{p}<0.001)$ lower than that produced by SSAAI (Fig. 1c). Subsequently, thrE and serE double deletion mutant was constructed, which exhibited cell growth comparable to that of SSAAI, and produced $10.34 \mathrm{~g} / \mathrm{L} \mathrm{L}$-serine, which was $60 \%(\mathrm{p}<0.001)$ lower than that observed in SSAAI (Fig. 3a, b).

Furthermore, thrE and serE were overexpressed alone or in combination in SSAAI to obtain SSAAI-thrE, SSAAI-serE, and SSAAI-serE-thrE. While L-serine accumulation in SSAAI-thrE was similar to that in SSAAI, the production of L-serine in SSAAI-serE reached $28.67 \mathrm{~g} / \mathrm{L}$, which was $10.5 \%(p<0.01)$ higher than that noted in SSAAI (Fig. 3a, c). However, a decrease in cell growth was observed in SSAAI-serE before $72 \mathrm{~h}$ of fermentation, when compared with that found in SSAAI (Fig. 3d). Furthermore, no significant difference in L-serine titer was found in the time courses of both SSAAI-serE and
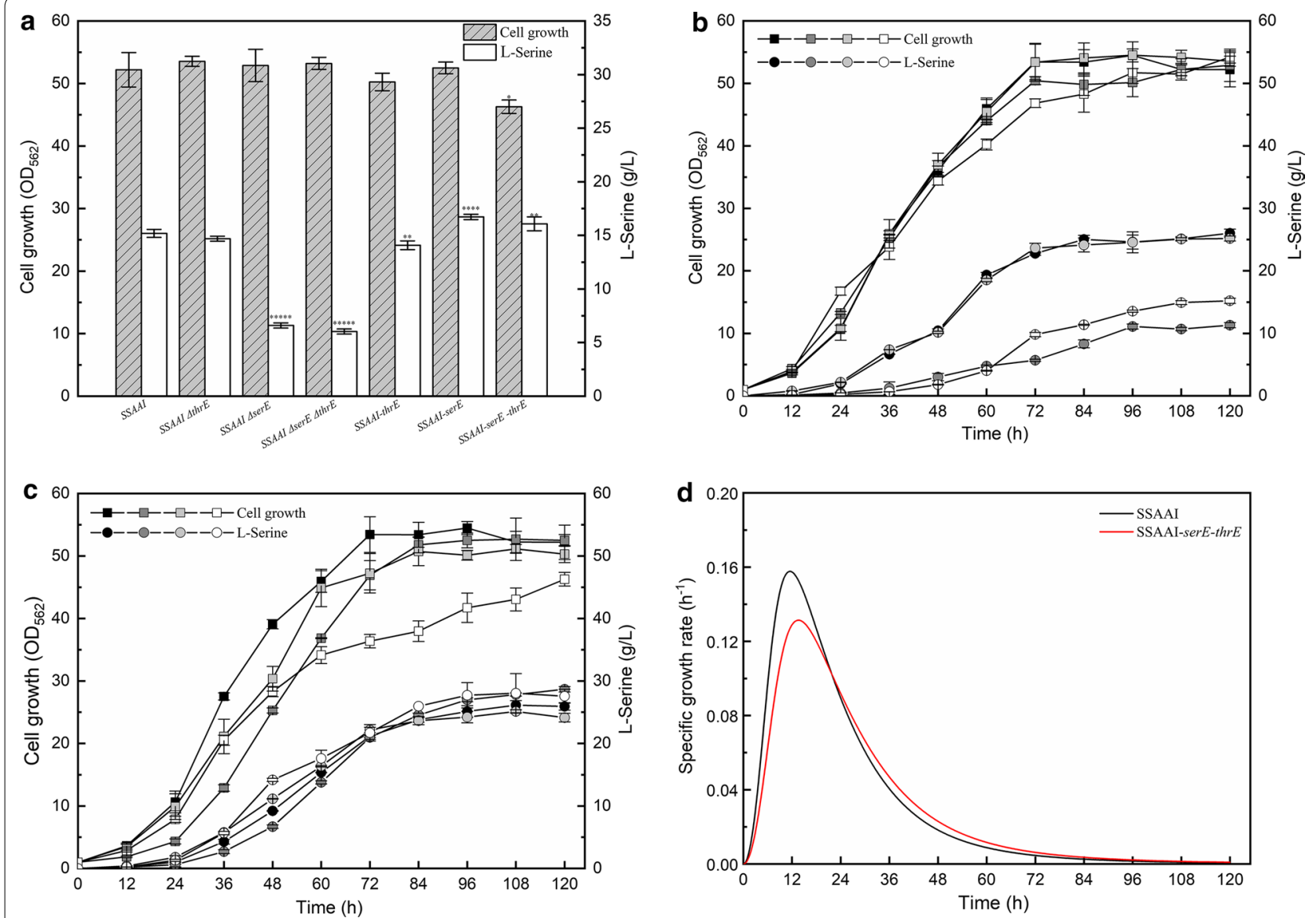

Fig. 3 Effect of the exporters thrE and serE deletion or overexpression on SSAAI. a Cell growth (gray bar with slash) and L-serine titer (white bar) of SSAAl, thrE deletion strain SSAAI $\triangle$ thrE, serE deletion strain SSAAI $\triangle$ serE, thrE and serE deletion strain SSAAI $\triangle$ serE $\triangle$ thrE, thrE overexpression strain SSAAl-thrE, serE overexpression strain SSAAl-serE, and thrE and serE double overexpression strain SSAAl-serE-thrE. b Cell growth (squares) and L-serine titer (circles) of SSAAI (black), serE deletion strain SSAAI $\triangle$ serE (dark gray), thrE deletion strain SSAAI $\triangle$ thrE (gray), and thrE and serE deletion strain SSAAI $\triangle$ serE $\triangle$ thrE (white). c Cell growth (squares) and L-serine titer (circles) of SSAAI (black), serE overexpression strain SSAAl-serE (dark gray), thrE overexpression strain SSAAl-thrE (gray), and thrE and serE double overexpression strain SSAAl-serE-thrE (white). d The growth rates of SSAAl-serE-thrE (red) and SSAAI (black) 
SSAAI-serE-thrE, and SSAAI-serE-thrE exhibited lower cell growth than SSAAI-thrE before $96 \mathrm{~h}$ of fermentation (Fig. 3c, d). These observations might be due to the inhibition of cell growth resulting from L-serine over-efflux, metabolic burden of overexpression of two membranebinding proteins, or inhibition of cell growth by L-threonine over-efflux. Taken together, these findings suggested that SerE plays a more important role than ThrE for L-serine export in SSAAI.

\section{Transcriptional regulator of the novel exporter SerE}

The gene NEWCgl0581, located upstream of $\operatorname{ser} E$ and divergently transcribed from $\operatorname{serE}$ (Additional file 1: Fig. S2), and its product (consisting of 303 amino acids) was found to be a member of the LysR-type transcriptional regulators (LTTRs) family. It must be noted that LTTRs were initially described as regulators of divergently transcribed genes [21]. In a previous study on C. glutamicum, LysG, located upstream of L-lysine exporter gene lysE, was observed to encode a LysR-type transcriptional regulator, confirming that LysG is a positive transcriptional regulator of lysE [22]. Accordingly, we speculated that NCgl0581 might be involved in the control of serE transcription.

To determine the function of NCgl0581, a mutant strain with $\mathrm{NCgl0581}$ deletion was constructed. As shown in Fig. 4a, the growth of SSAAI $\triangle$ NCgl0581 was similar to that of the parent strain SSAAI. However, the $\mathrm{L}$-serine titer of SSAAI $\triangle \mathrm{NCgl0581}$ was $11.08 \mathrm{~g} / \mathrm{L}$, which was $57.4 \%(\mathrm{p}<0.001)$ lower than that of the parent strain, indicating that NCgl0581 played an important role in L-serine production. Subsequently, the effect of NCgl0581 on serE expression was further investigated by using the probe plasmid pDXW-11. Two recombinant strains, SSAAI $\triangle \mathrm{NCgl0581-1} \mathrm{(harboring} \mathrm{the} \mathrm{plasmid}$ pDXW-11-1, Fig. 4b) and SSAAI $\triangle$ NCgl0581-0 (harboring the plasmid pDXW-11-0, Fig. 4c) were constructed, and their fluorescence during fermentation was measured. The fluorescence of SSAAI $\triangle \mathrm{NCgl0581-1}$ was stronger than that of SSAAI $\triangle \mathrm{NCgl0581-0}$ during the fermentation process (Fig. 4d), revealing that NCgl0581 functioned as a positive regulator of serE expression. To verify whether the regulatory protein $\mathrm{NCgl0581}$ binds to the upstream region of SerE, EMSA was performed by using the DNA probe labeled with biotin, and the result clearly indicated that $\mathrm{NCgl0581}$ binds to this region (Fig. 4e).

To confirm whether NCgl0581 is a specific regulator of SerE, transcriptome sequencing was performed using SSAAI and NCgl0581 deletion strain. The findings showed that the transcription levels of 115 genes were altered, including 56 upregulated genes and 59 downregulated genes, in response to $\mathrm{NCgl0581}$ deletion, indicating that $\mathrm{NCgl0581}$ is a global transcriptional regulator in C. glutamicum. The genes with significant transcriptional change ( $\geq$ fourfold) are shown in Tables 1 and 2.

The transcriptional level of serE was significantly decreased by 280-fold following NCgl0581 deletion, revealing that $\mathrm{NCgl0581}$ is a positive regulator of serE. Furthermore, NCgl0581 deletion downregulated the two $\mathrm{ABC}$ transporter permeases ( $\mathrm{NCgl0638}$ and $\mathrm{NCgl0484)}$ and $\mathrm{ABC}$ transporter periplasmic component (NCgl0639) by 12-, 6.3-, and 7.5-fold, respectively, and upregulated $\mathrm{ABC}$ transporter periplasmic component (NCgl1405) by 5.88 -fold, suggesting that NCgl0581 is involved in the synthesis of substances transported through $\mathrm{ABC}$ transporter.

\section{Overexpression of SerE and NCgl0581}

As NCgl0581 could activate the expression of SerE in SSAAI, the overexpression of NCgl0581, serE, or their co-expression was studied, and strains SSAAI-NCgl0581 and SSAAI-NCgl0581-serE were constructed, respectively. As shown in Fig. 5a, b, a decrease in cell growth was observed in SSAAI-NCgl0581-serE and SSAAINCgl0581 before $96 \mathrm{~h}$ of fermentation, and SSAAINCgl0581-serE showed the lowest growth rate, the time courses for L-serine production were similar in all the strains. Furthermore, the yield of $\mathrm{L}$-serine to biomass $(\mathrm{Yp} / \mathrm{x})$ increased in both SSAAI-NCgl0581-serE and SSAAI-NCgl0581 (Fig. 5c, d), suggesting that overexpression of a novel exporter SerE and its transcriptional regulator NCgl0581 was beneficial for L-serine efflux, but not for cell growth. Besides, SSAAI-NCgl0581-serE and SSAAI-NCgl0581 exhibited 9.67\% $(\mathrm{p}<0.05)$ and $19.17 \%$ $(\mathrm{p}<0.01)$ higher $\mathrm{Yp} / \mathrm{x}$ in $96 \mathrm{~h}$, respectively, when compared with SSAAI. A similar decrease in cell growth was observed in SSAAI-serE (Fig. 3c); however, the L-serine titer was $28.67 \mathrm{~g} / \mathrm{L}$, which was $10.5 \%(\mathrm{p}<0.01)$ higher than that noted in SSAAI. This decrease in cell growth in the recombinant strain could be due to the transportation of the synthesized L-serine out of the cell, resulting in inadequate intracellular L-serine for cell growth. Therefore, our subsequent investigation involved replenishment of L-serine by overexpressing L-serine synthetic pathway key enzyme.

\section{High yield production of L-serine through SerE combined with synthetic pathway}

To direct more flux to L-serine synthesis, L-serine exporter SerE and L-serine synthetic pathway key enzyme (containing a feedback insensitive ser $A \Delta 197$, $\operatorname{ser} C$, and $\operatorname{ser} B$ encoding the deregulated 3-phosphoglycerate dehydrogenase, phosphoserine phosphatase, and phosphoserine aminotransferase, respectively) 


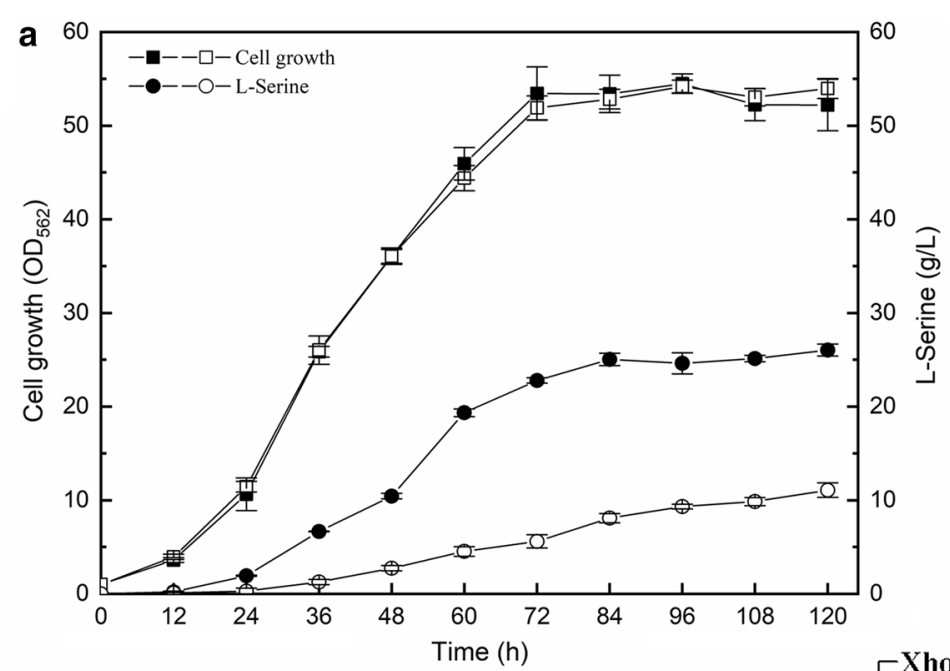

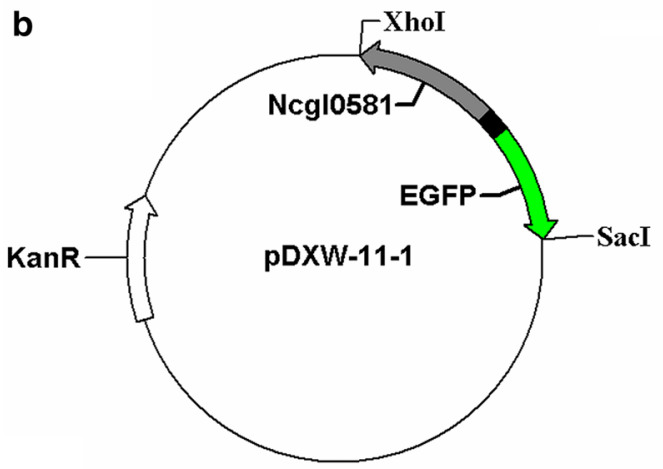

d

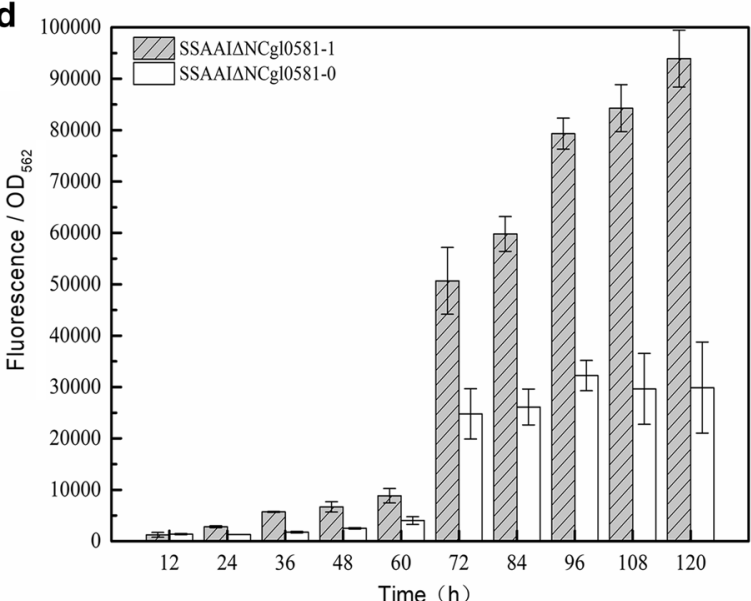

C

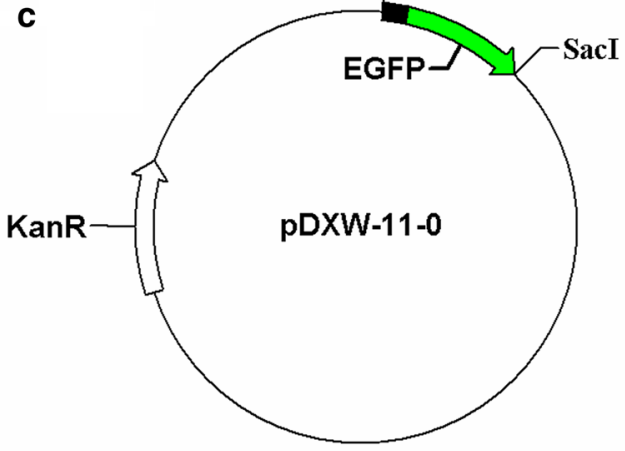

e

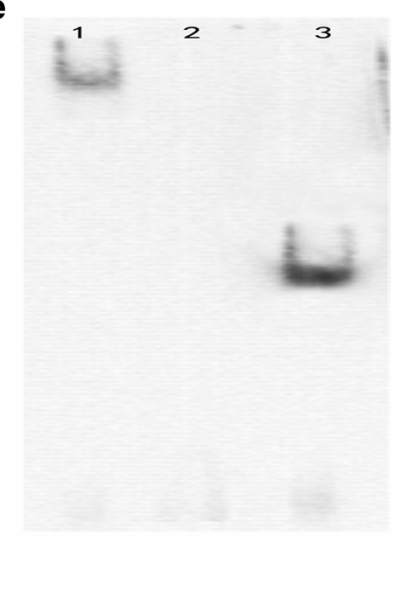

Fig. 4 Verification of the function of NCgI0581. a The cell growth (squares) and L-serine titer (circles) of SSAAI (solid symbols) and NCgl0581 deletion strain SSAAI $\triangle N C$ C 0581 (open symbols), respectively. b Plasmid pDXW-11-1 containing fragments of NCgl0581 (gray), intergenic region between NCgl0581 and NCgl0580 (black), and EGFP (green). c Plasmid pDXW-11-0 containing fragments of the intergenic region between NCgl0581 and NCgl0580 (black) and EGFP (green). d Fluorescence of the two strains, SSAAI $\triangle$ NCgl0581-1 (gray bar with slash) and SSAAI $\mathrm{NCgl0581-0} \mathrm{(white} \mathrm{bar).}$ e Verification of NCgI0581 binding to the upstream region of SerE by using EMSA. Lane 1: the nuclear extracts with activated specific TF (positive control), Lane 2: the nuclear extracts without activated TF (negative control), Lane 3: Sample

were co-overexpressed in SSAAI to obtain SSAAI-serEserA $\triangle 197$-serC-serB. The recombinant strain shared similar typical growth curves as the parent strain SSAAI, and achieved a final L-serine titer of $32.8 \mathrm{~g} / \mathrm{L}$, which was $22.1 \%(\mathrm{p}<0.001)$ higher than that noted in SSAAI.

Subsequently, to further improve L-serine titer, L-serine exporter $\operatorname{ser} E, \operatorname{ser} A \Delta 197, \operatorname{ser} C$ and $\operatorname{ser} B$ were 
Table 1 Genes significantly upregulated by NCgl0581 deletion

\begin{tabular}{|c|c|c|c|c|}
\hline Gene id & SSAAI $\Delta 0581$ & SSAAI & Fold change & Protein function \\
\hline NCgl2897 & 701.56 & 71.07 & 9.87 & Starvation-inducible DNA-binding protein \\
\hline NCgl0546 & 17.78 & 2.75 & 6.45 & Hypothetical protein \\
\hline NCgl1405 & 15.94 & 2.71 & 5.88 & $\mathrm{ABC}$ transporter periplasmic component \\
\hline NCgl1302 & 10.05 & 1.96 & 5.13 & Aldo/keto reductase \\
\hline NCgl1344 & 286.87 & 55.96 & 5.12 & Ornithine carbamoyltransferase \\
\hline NCgl1343 & 280.65 & 57.24 & 4.9 & Acetylornithine aminotransferase \\
\hline NCgl0746 & 43.30 & 9.04 & 4.7 & Hypothetical protein \\
\hline NCgl1342 & 134.70 & 29.07 & 4.63 & Acetylglutamate kinase \\
\hline NCgl2946 & 672.93 & 155.87 & 4.31 & Hypothetical protein \\
\hline NCgl1022 & 89.53 & 21.28 & 4.20 & Cysteine sulfinate desulfinase \\
\hline NCgl1023 & 368.88 & 88.67 & 4.15 & Nicotinate-nucleotide pyrophosphorylase \\
\hline NCgl1341 & 108.49 & 27.09 & 4.00 & $\begin{array}{l}\text { Bifunctional ornithine acetyltransferase/N- } \\
\text { acetylglutamate synthase }\end{array}$ \\
\hline
\end{tabular}

Table 2 Genes significantly downregulated by NCgl0581 deletion

\begin{tabular}{|c|c|c|c|c|}
\hline Gene id & SSAAI $\Delta 0581$ & SSAAI & Fold change & Protein function \\
\hline NCgl0580 & 18.40 & 5152.54 & 280.02 & Hypothetical protein \\
\hline NCgl0638 & 1.71 & 20.97 & 12.22 & $\mathrm{ABC}$ transporter permease \\
\hline NCgl0639 & 11.00 & 82.47 & 7.49 & ABC transporter periplasmic component \\
\hline NCgl2943 & 207.03 & 1355.55 & 6.54 & Hypothetical protein \\
\hline NCgl0943 & 16.19 & 103.52 & 6.39 & AraC family transcriptional regulator \\
\hline NCgl0484 & 2.32 & 14.57 & 6.28 & ABC transporter permease \\
\hline NCgl2942 & 283.52 & 1776.15 & 6.26 & NADH:flavin oxidoreductase \\
\hline NCgl0166 & 13.41 & 79.70 & 5.94 & Hypothetical protein \\
\hline NCgl0324 & 2.11 & 11.87 & 5.61 & Zn-dependent alcohol dehydrogenase \\
\hline NCgl0282 & 5.19 & 28.25 & 5.44 & 4-Hydroxyphenyl-beta-ketoacyl-CoA hydrolase \\
\hline NCgl1975 & 102.94 & 503.75 & 4.89 & Hypothetical protein \\
\hline NCgl2893 & 1.25 & 6.08 & 4.84 & Efflux system protein \\
\hline NCgl0155 & 9.11 & 43.69 & 4.79 & 5-Dehydro-2-deoxygluconokinase \\
\hline NCgl0014 & 10.02 & 47.76 & 4.76 & Hypothetical protein \\
\hline NCgl2953 & 7.68 & 35.80 & 4.66 & Sugar permease \\
\hline NCgl2744 & 12.26 & 55.19 & 4.50 & Hypothetical protein \\
\hline NCgl2970 & 15.22 & 67.51 & 4.43 & $\mathrm{ABC}$ transporter periplasmic component \\
\hline NCgl0608 & 23.06 & 100.35 & 4.35 & $\mathrm{ABC}$ transporter permease \\
\hline NCgl0258 & 4.51 & 19.50 & 4.32 & Arsenite efflux pump ACR3 \\
\hline NCgl0281 & 16.83 & 67.69 & 4.02 & Dehydrogenase \\
\hline
\end{tabular}

overexpressed in strain A36, which was stemmed from SSAAI by using ARTP mutation [23]. As shown in Fig. 6, no significant changes can be observed for cell growth and sucrose consumption between strain A36-serEser $A \Delta 197$-serC-ser $B$ and its control strain A36-ser $A \Delta 197$ serC-ser $B$ as well as the parent strain A36. Interestingly, when the incubation time of batch cultivation exceeded $84 \mathrm{~h}, \mathrm{~L}$-serine titer of A36-serE-serA $\Delta 197-\operatorname{ser} C$-ser $B$ were higher than A36-serA $\Delta 197$-serC-serB. After $120 \mathrm{~h}$ of cultivation, A36-serE-serAD197-serC-serB consumed all of the sucrose and achieved a final L-serine titer of $43.9 \mathrm{~g} / \mathrm{L}$, with a conversion rate of $0.44 \mathrm{~g} / \mathrm{g}$, which is $15.8 \%(\mathrm{p}<0.01)$ and $15.8 \%(\mathrm{p}<0.01)$ higher than the control strain A36-serA $\Delta 197-\operatorname{ser} C$-serB $(37.9 \mathrm{~g} / \mathrm{L}, 0.38 \mathrm{~g} / \mathrm{g})$, $43.5 \%(\mathrm{p}<0.001)$ and $41.9 \%(\mathrm{p}<0.001)$ higher than the parent strain A36 (30.6 g/L, $0.31 \mathrm{~g} / \mathrm{g})$, respectively. These results demonstrated that overexpression of L-serine exporter in combination with L-serine synthetic pathway could facilitate L-serine production in C. glutamicum. 

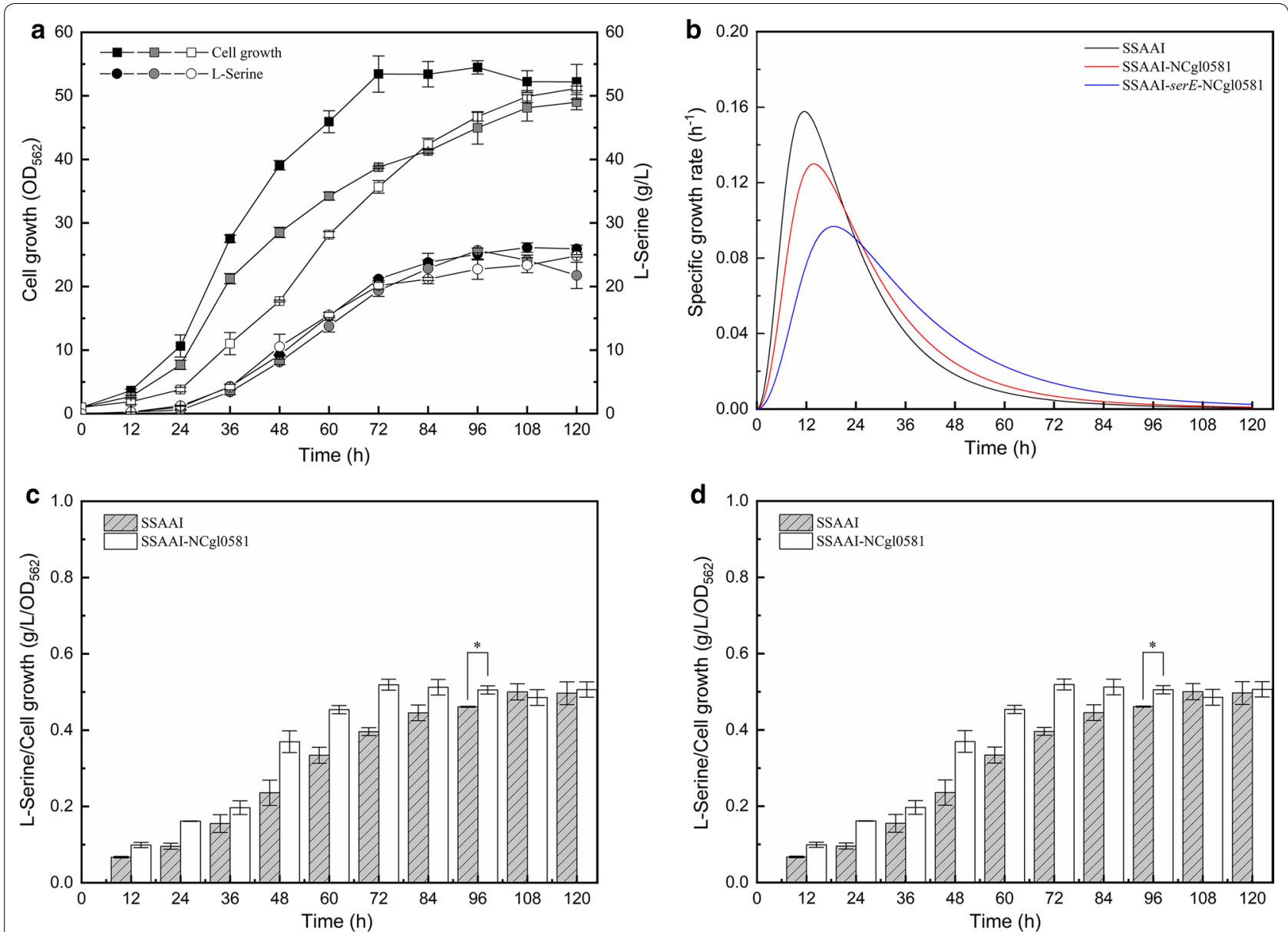

Fig. 5 Effect of serE and NCgl0581 deletion or overexpression on SSAAI. a Cell growth (squares) and L-serine titer (circles) of SSAAI (black), NCgl0581 overexpression strain SSAAI-NCgl0581 (gray), and NCgl0581 and serE double overexpression strain SSAAI-NCgI0581-serE (white). b The growth rates of SSAAI-NCgI0581 (red), SSAAI-NCgI0581-serE (blue) and SSAAI (black). c Yp/x of SSAAI (gray bar with slash) and NCgl0581 overexpression strain SSAAI-NCgl0581 (white bar). d Yp/x of SSAAI (gray bar with slash) and NCgl0581 and serE double overexpression strain SSAAI-NCgl0581-serE (white bar)

\section{Discussion}

Transport engineering is becoming an attractive strategy for strain improvement [11, 16, 17]. However, only a relatively limited number of exporters of amino acids have been identified in C. glutamicum (Additional file 1: Table S1) [8, 12, 14-17, 24-27]. In this study, SerE was identified as a novel L-serine exporter in C. glutamicum. Further analysis showed that SerE could also export L-threonine (Fig. 2c), but not L-cysteine, similar to ThrE, which could export both $\mathrm{L}$-serine and $\mathrm{L}$-threonine in $C$. glutamicum [15]. It was assumed that the presence of $\mathrm{OH}$ in both L-serine and L-threonine might be the reason for these exporters to transport the two substrates. Based on homology search, SerE was found to be similar to a member of the DMT superfamily. Although DMT superfamily proteins are involved in the transport of a wide range of substrates, there are only a few reports available on their structures and mechanisms of substrate transport. Christian et al. performed structural and functional analyses of YddG, a DMT protein, and provided insight into the common transport mechanism shared among the DMT superfamily members [28]. It has been reported that analyses of the crystal structure data of exporters could help to elucidate the elusive transport mechanism [29], and in the future, we will further investigate the SerE structures and mechanisms of substrate transport.

To explore the interaction between the known L-serine exporter ThrE and the novel exporter SerE on L-serine export, ThrE and SerE single and double mutants were constructed. The results showed that serE and thrE double deletion mutant could still accumulate $10.34 \mathrm{~g} / \mathrm{L}$ L-serine (Fig. 3b), suggesting that C. glutamicum might also possess other L-serine exporter systems. The evolution of multiple exporter systems for a single substrate is beneficial for the survival of bacteria in variable 


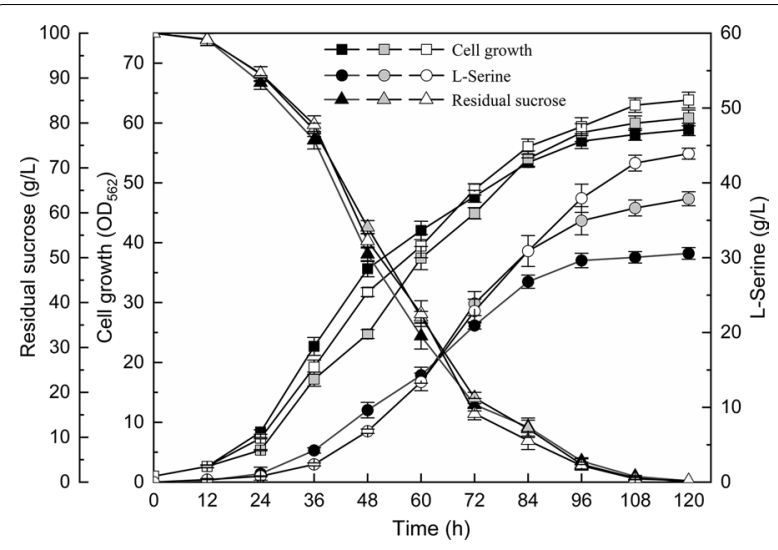

Fig. 6 Fermentation process of strain A36 and strain A36-serE-serA $\triangle 197$-serC-serB. The cell growth (squares), L-serine titer (circles), and residual sucrose (triangles) of strain A36 (black), A36-serA $\triangle 197-$ serC-serB (gray) and A36-serE-serA $\triangle 197-$ serC-serB (white) are presented. Three parallel experiments were performed. Error bars indicate standard deviations of the results from three parallel experiments

environment $[7,30]$. It must be noted that overexpression of serE in SSAAI resulted in $10.5 \%(\mathrm{p}<0.01)$ increase in $\mathrm{L}$-serine titer, but a decrease in cell growth. This could be due to the use of constitutive-type promoter to overexpress SerE, causing higher L-serine efflux. As sufficient L-serine content is important to maintain cell growth, a decrease in cell growth was noted as a stress response to serE overexpression. In future studies, better tuning of the serE expression must be achieved in SSAAI by testing different promoters and RBS. When thrE and serE were co-overexpressed in SSAAI, SSAAI-serE-thrE exhibited lower cell growth than SSAAI, but an L-serine titer similar to that of SSAAI-serE (Fig. 3c). A severe decline in cell growth was observed in all exporter overexpression strains, which may be caused by the accumulation of $\mathrm{L}$-serine in the medium as well as additional burden on the cell overexpressing the exporters, similar to that reported by Mundhada et al. [31].

NCgl0581 was identified as the transcriptional regulator of the novel L-serine exporter SerE, and EMSA was performed to confirm the binding sites of NCgl0581 with the promoter of SerE. A previous study reported that the first member of the protein-gene pairs, ArgP$\operatorname{argO}$ in E. coli and LysG-lysE in C. glutamicum, is a LysR-type transcriptional regulator, while the second member is its target gene encoding an amino acid exporter [22, 32, 33]. Similarly, NCgl0581-serE might also be a protein-gene pair sharing the same regulation mechanism. A serine biosensor based NCgl0581 was reported by Binder et al. [34], and accordingly, we constructed a biosensor for L-serine and found that NCgl0581 activated NCgl0580 (SerE) expression in the presence of L-serine, with expression of SerE enhancing with increasing L-serine titer [23]. However, NCgl0581 did not activate the expression of SerE in the presence of $\mathrm{L}$-alanine and $\mathrm{L}$-valine. To further confirm whether SerE could export L-alanine and L-valine, peptide feeding assays were employed using dipeptides (Ala-Ala, Val-Val) with SSAAI and SSAAI $\Delta s e r E$. The results revealed that SerE could neither export L-alanine nor L-valine (data not shown). Moreover, transcriptome sequencing showed that $\mathrm{NCgl0581}$ regulated 115 genes in C. glutamicum, suggesting that NCgl0581 was a novel global transcriptional regulator in C. glutamicum. Transcriptional regulators and their roles in expression control of target genes are important for metabolic engineering of C. glutamicum for industrial applications [35], and the present study provided a new member of transcriptional regulator family.

Overexpression of SerE alone in SSAAI resulted in $10.8 \%$ increase in L-serine titer and a simultaneous decrease in cell growth, implying that the synthesized L-serine was transported out of the cell, and that the intracellular L-serine was not adequate for cell growth. When L-serine was replenished by overexpressing L-serine synthetic pathway key enzyme, the cell growth was restored and L-serine titer increased to $43.9 \mathrm{~g} / \mathrm{L}$, with an L-serine yield of $0.44 \mathrm{~g} / \mathrm{g}$ sucrose, which are the highest yield reported so far for $C$. glutamicum. These results indicated that $\operatorname{ser} A \Delta 197, \operatorname{ser} C$, and $\operatorname{ser} B$ overexpression ensured sufficient L-serine supply preventing cell growth inhibition. In previous studies by Mundhada et al. $37 \mathrm{~g} / \mathrm{L} \mathrm{L}$-serine was produced with a yield of $0.24 \mathrm{~g} / \mathrm{g}$ glucose in $E$. coli [2], and $11.7 \mathrm{~g} / \mathrm{L} \mathrm{L}$-serine titer was achieved with the highest yield of $0.43 \mathrm{~g} / \mathrm{g}$ glucose [31]. Interestingly, in the present study, we found that the L-serine titer significantly increased with $\operatorname{ser} B$ overexpression in A36, producing an L-serine titer of $37.9 \mathrm{~g} / \mathrm{L}$, which was $24 \%$ higher than that in A36. It must be noted that $\operatorname{ser} B$ encodes phosphoserine phosphatase (PSP, EC 3.1.3.3), which catalyzes the last step of L-serine biosynthesis. However, L-serine titer did not significantly change when $\operatorname{ser} A \Delta 197$ and $\operatorname{ser} C$ were respectively overexpressed in A36 (with L-serine titer of 31.1 and $32.78 \mathrm{~g} / \mathrm{L}$, respectively). In a recent study, $50 \mathrm{~g} / \mathrm{L} \mathrm{L}$-serine was produced with glucose as the carbon source in $E$. coli, which is the highest L-serine production reported so far; however, the yield was $0.36 \mathrm{~g} / \mathrm{g}$ glucose [36], which is lower than that obtained in the present study $(0.44 \mathrm{~g} / \mathrm{g}$ sucrose). Therefore, fine controlling of the three enzymes of L-serine biosynthesis pathway could possibly further enhance L-serine production. 


\section{Conclusion}

In the present study, a novel exporter SerE and its positive regulator NCgl0581 were identified in C. glutamicum. SerE exhibited the ability to export $\mathrm{L}$-threonine and NCgl0581 acting as a novel global transcriptional regulator in C. glutamicum, and by overexpressing this novel exporter along with L-serine synthetic pathway enzyme, significant increase in L-serine yield could be achieved. These results enrich our understanding of amino acid transport and can provide additional targets for exporter engineering in C. glutamicum.

\section{Materials and methods}

\section{Strains, plasmids, and growth conditions}

The strains and plasmids used in this study are listed in Table 3. E. coli JM109 was used as the cloning host, and was grown in lysogeny broth (LB) medium (containing $5.0 \mathrm{~g} / \mathrm{L}$ yeast extract, $10.0 \mathrm{~g} / \mathrm{L}$ tryptone, and $10.0 \mathrm{~g} / \mathrm{L} \mathrm{NaCl})$ at $37{ }^{\circ} \mathrm{C}$ and $220 \mathrm{rpm}$. The engineered SSAAI (CGMCC No.15170) was selected as the original strain, which constructed in our laboratory by knocking out $591 \mathrm{bp}$ of the C-terminal domain of $\operatorname{ser} A$, deleting $s d a A, a v t A$, and alaT, as well as attenuating $i l v B N$ in the genome of C. glutamicum SYPS-062-33a (CGMCC No. 8667). Strain A36 derived from SSAAI by ARTP mutation, with higher L-serine titer and yield than SSAAI. The seed and fermentation media for C. glutamicum were prepared as described previously [5]. The C. glutamicum strains were pre-incubated in the seed medium overnight to an optical density $\left(\mathrm{OD}_{562}\right)$ of about 25 , and then inoculated at an initial concentration of $\mathrm{OD}_{562}=1$ into a $250 \mathrm{~mL}$ flask containing $25 \mathrm{~mL}$ of the fermentation medium at $30{ }^{\circ} \mathrm{C}$ and $120 \mathrm{rpm}$. The antibiotic kanamycin $(50 \mathrm{mg} / \mathrm{L})$ was added when necessary. Samples were withdrawn periodically for the measurement of residual sugar, amino acids, and $\mathrm{OD}_{562}$ as described previously [5].

\section{Construction of plasmids and strains}

The primers used in this study for gene expression/deletion are listed in Additional file 1: Table S2. Gene deletion was performed using the nonreplicable deletion vector pK18mobsacB, as reported previously [37]. For example, to achieve thrE deletion, the homologousarm fragments for thrE deletion were amplified from SSAAI chromosome using the primer pairs $t h r E 1 / 2$ for the upstream fragment and $t h r E 3 / 4$ for the downstream fragment. Then, with the two fragments as templates, a crossover PCR was performed using the primer pair $t h r E 1 / 4$. The truncated product of $t h r E$ was digested with $X b a \mathrm{I}$ and HindIII and ligated to the vector pK18mob$s a c B$ that was similarly treated. The recombinant plasmid
pK18mobsacB $\Delta$ thrE was transformed into SSAAI competent cells by electroporation, and chromosomal deletion was performed by selecting cells that were kanamycin resistant and sucrose nonresistant, and verified by PCR.

The pDXW-10 and pDXW-11 plasmids were used to overexpress genes in C. glutamicum [38, 39]. The recombinant plasmids were constructed as follows: the genes thrE and $\operatorname{ser} E$ were amplified, digested, and ligated to the pDXW-10 plasmid that was digested with HindIII/BglII. The plasmid harboring the fusion protein, EGFP-SerE (enhanced green fluorescent protein), was constructed by using the method reported in a previous study [19]. To confirm the role of NCgl0581 on NCgl0580 expression, the fragment consisting of intergenic region of NCgl0581 and NCgl0580 and EGFP with or without NCgl0581 was ligated to the plasmid pDXW-11 by Clon Express MultiS One Step Cloning Kit (Vazyme, Nanjing, China). The strains were constructed by electroporation with the corresponding plasmids.

The genes, ser $A \triangle 197, \operatorname{ser} C$, and $\operatorname{ser} B$, were PCR amplified from SSAAI using primers shown in Additional file 1: Table S2. To construct plasmid pDXW10-serA $\triangle 197$, the resultant fragment of $\operatorname{ser} A \Delta 197$ was digested with EcoRI and NotI and cloned into pDXW-10. To construct plasmid pDXW-10-serA $\Delta 197-\operatorname{ser} C$-serB, the PCR fragments of $\operatorname{ser} B$ and $\operatorname{ser} C$ were digested with appropriate restriction enzymes and successively cloned into the corresponding plasmids to form plasmid pDXW10-serA $\Delta 197$-serC-serB. The resulting plasmid (pDXW10-serA $\Delta 197$-serC-serB) was then subjected to double digestion by NdeI and PacI for cloning of NCgl0580 to obtain pDXW-10-serE-serAD197-serC-serB.

\section{Confocal microscopic observation}

The strains SSAAI-10 (SSAAI-harboring plasmid pDXW10), SSAAI-egfp, and SSAAI-serE-egfp were grown in the seed medium and harvested during the exponential phase. The cells were washed twice and maintained in PBS ( $\mathrm{pH}$ 7.4), mounted on a microscope slide, and observed under a Leica laser scanning confocal microscope (Leica, TCS SP8; Leica, Wetzlar, Germany) equipped with a HC PL Apo 63x/1.40 Oil CS2 oilImmersion objective, with excitation filter at $488 \mathrm{~nm}$ and emission filter at 510-550 $\mathrm{nm}$. The digital images were acquired and analyzed with Lecia Application Suite X 2.0.

\section{Membrane and cytoplasmic protein extraction and fluorescence measurements}

The strains SSAAI-10, SSAAI-egfp, and SSAAI-serE-egfp were used for extracting membrane and cytoplasmic proteins to determine SerE localization. The extraction was performed using Membrane and a Cytoplasmic Protein 
Table 3 Strains and plasmids used in this study

\begin{tabular}{|c|c|c|}
\hline Strain/plasmid & Description & Sources or reference \\
\hline \multicolumn{3}{|l|}{ E. coli } \\
\hline JM109 & recA1, endA1, gyrA96, thi-1, hsdR17, supE44, relA1 & Laboratory strain \\
\hline \multicolumn{3}{|l|}{ C. glutamicum } \\
\hline SSAAI & $\begin{array}{l}\text { C. glutamicum SYPS-33a with deletion of the } 591 \text { bp in the C-terminus of serA, deletion of } \\
\text { sdaA,alaT,avta and attenuation of ilvBN }\end{array}$ & {$[5]$} \\
\hline A36 & SSAAI mutant strain & {$[23]$} \\
\hline SSAAI-thrE & SSAAI harboring plasmid pDXW-10-thrE & This study \\
\hline SSAAIDthrE & SSAAI with deletion of thrE & This study \\
\hline SSAAI $\triangle N C g \mid 2050$ & SSAAI with deletion of NCgl2050 & This study \\
\hline SSAAI $\triangle N C g \mid 2065$ & SSAAI with deletion of NCgl2065 & This study \\
\hline SSAAI $\triangle N C g \mid 0580$ & SSAAI with deletion of NCgl0580 & This study \\
\hline SSAAI-10 & SSAAI harboring plasmid pDXW-10 & This study \\
\hline SSAAI-egfp & SSAAI harboring plasmid pDXW-10-egfp & This study \\
\hline SSAAI-serE-egfp & SSAAI harboring plasmid pDXW-10-serE-egfp & This study \\
\hline SSAAI-NCgl0581 & SSAAI harboring plasmid pDXW-10- NCgl0581 & This study \\
\hline SSAAI-NCgl0581-serE & SSAAI harboring plasmid pDXW-10- NCgl0581-serE & This study \\
\hline SSAAI $\triangle N C g \mid 0581$ & SSAAI with deletion of NCgl0581 & This study \\
\hline SSAAI $\triangle$ NCgI0581-1 & SSAAI $\triangle N C g \mid 0581$ harboring pDXW-11-1 & This study \\
\hline SSAAI $\triangle N C g \mid 0581-0$ & SSAAI $\triangle N C g I 0581$ harboring pDXW-11-0 & This study \\
\hline SSAAI $\triangle$ NCgl0580- NCgl0580 & SSAAI $\Delta$ serE harboring plasmid pDXW-10-serE (NCgl0580) & This study \\
\hline SSAAI-serE & SSAAI harboring plasmid pDXW-10-serE (NCgl0580) & This study \\
\hline ATCC13032 & Wild type & Laboratory strain \\
\hline ATCC13032 $\triangle$ serE & ATCC13032 with deletion of serE (NCgl0580) & This study \\
\hline pK18mobsacB & Integration vector, oriV, oriT, mob, sacB, $\mathrm{Km}^{r}$ & {$[37]$} \\
\hline pK18mobsacB $\triangle$ thre & $\begin{array}{l}\text { pK18mobsacB carrying the up- and downstream homologous fragments of thrE gene for thrE } \\
\text { deletion }\end{array}$ & This study \\
\hline pK18mobsacB $\triangle \mathrm{NCgl} 2050$ & $\begin{array}{l}\text { pK18mobsacB carrying the up- and downstream homologous fragments of NCgl2050 gene for } \\
\text { NCgl2050 deletion }\end{array}$ & This study \\
\hline pK18mobsacBANCgl2065 & $\begin{array}{l}\text { pK18mobsacB carrying the up- and downstream homologous fragments of NCgl2065 gene for } \\
\text { NCgl2065 deletion }\end{array}$ & This study \\
\hline pK18mobsacB $\triangle \mathrm{NCg} \mid 0580$ & $\begin{array}{l}\text { pK1 } 8 \text { mobsacB carrying the up- and downstream homologous fragments of NCgl0580 gene for } \\
\text { NCgl0580 deletion }\end{array}$ & This study \\
\hline pK18mobsacB $\triangle \mathrm{NCg} \mid 0581$ & $\begin{array}{l}\text { pK18mobsacB carrying the up- and downstream homologous fragments of NCgl0581 gene for } \\
\text { NCgl0581 deletion }\end{array}$ & This study \\
\hline pDXW-10 & E. coli-C. glutamicum shuttle vector, tacM promoter, $\mathrm{Km}^{\mathrm{r}}$ & [38] \\
\hline pDXW-10-thrE & pDXW-10 carrying the gene of thrE & This study \\
\hline pDXW-10-serE & pDXW-10 carrying the gene of serE & This study \\
\hline pDXW-10-egfp & pDXW-10 carrying the gene of egfp & This study \\
\hline pDXW-10-egfp-serE & pDXW-10 carrying the gene of egfp and serE for the expression of fusion protein EGFP-SerE & This study \\
\hline pDXW-10- NCgl0581 & pDXW-10 carrying the gene of NCgl0581 & This study \\
\hline pDXW-10- NCgl0581-serE & pDXW-10 carrying the gene of NCgl0581 and serE & This study \\
\hline pDXW-11 & E. coli-C. glutamicum shuttle vector, probe plasmid, $\mathrm{Km}^{r}$ & [39] \\
\hline pDXW-11-1 & $\begin{array}{l}\text { pDXW-11 carrying the fragments of NCgl0581, the intergenic region between NCgl0581 and } \\
\text { NCgl0580, and egfp }\end{array}$ & This study \\
\hline pDXW-11-0 & $\begin{array}{l}\text { pDXW-11 carrying the fragments of the intergenic region between NCgl0581 and NCgl0580, } \\
\text { and egfp }\end{array}$ & This study \\
\hline
\end{tabular}

$K m^{r}$ kanamycin resistance

Extraction Kit according to the manufacturer's protocol (Beyotime, Nanjing, China). The cells were washed twice with PBS ( $\mathrm{pH}$ 7.4) and disrupted by ultrasonication on ice (pulse, $4 \mathrm{~s}$; interval, $6 \mathrm{~s}$; total duration, $30 \mathrm{~min}$ ) (Sonics Vibra-Cell ${ }^{\mathrm{TM}}$, Sonics, Newtown, CT, USA). The supernatant containing cytoplasmic proteins was collected by 
centrifugation $\left(700 \times g, 4{ }^{\circ} \mathrm{C}\right.$ for $\left.10 \mathrm{~min}\right)$, and the precipitate was used for extracting membrane proteins. The protein concentration was determined with a Modified BCA Protein Assay Kit (Sangon, China). After extraction, the fluorescence intensity (excitation at $488 \mathrm{~nm}$, emission at $517 \mathrm{~nm}$ ) of the membrane and cytoplasmic proteins was determined using fluorescence spectrophotometer (Synergy H4; BioTek, Winooski, VT, USA).

\section{Amino acid export assay}

For ascertaining the function of $\operatorname{serE}$, a dipeptide SerSer addition assay was performed [15]. In brief, the preincubated cells (in seed medium) were washed once with CGXII minimal medium [40], inoculated into CGXII minimal medium with $2 \mathrm{mM}$ Ser-Ser (other dipeptide), and incubated for $2 \mathrm{~h}$ at $30{ }^{\circ} \mathrm{C}$. Then, the cells were harvested, washed once with cold CGXII minimal medium, and resuspended in CGXII minimal medium. Amino acid excretion was initiated by adding $2 \mathrm{mM}$ Ser-Ser (other dipeptide). HPLC was used to determine the concentrations of amino acids [19].

\section{Analytical procedures}

Cell density $\left(\mathrm{OD}_{562}\right)$ was measured using an AOE UV$1200 \mathrm{~S} \mathrm{UV} / v i s$ spectrophotometer (AOE Instruments Co. Inc., Shanghai, China). Sugar concentration was determined using SBA-40E glucose analyzer (Biology Institute of Shandong Academy of Sciences, China). For measurement of extracellular L-serine concentration in shake-flask fermentation, $500 \mu \mathrm{L}$ of the culture were centrifuged at $700 \times g$ for $5 \mathrm{~min}$, and the supernatant was used for detection after appropriate dilution. To ascertain intracellular $\mathrm{L}$-serine concentration, $300 \mu \mathrm{L}$ of the culture were centrifuged at $700 \times g$ and $4{ }^{\circ} \mathrm{C}$ for $10 \mathrm{~min}$, and $300 \mu \mathrm{L}$ of water were added to the cells. The cells were disrupted by FastPrep-24 $5 \mathrm{G}$ instrument $(5 \mathrm{~m} / \mathrm{s}, 120 \mathrm{~s}$, MP Biomedicals, Shanghai, China). The cytoplasmic volume was assumed to be $2 \mu \mathrm{L} / \mathrm{mg}$ dry cell weight [27]. The titers of intracellular and extracellular $\mathrm{L}$-serine and other amino acids were analyzed by HPLC using phenyl isothiocyanate as a precolumn derivatization agent, according to our previously study [8].

\section{EMSA}

To identify the binding site of NCgl0581 in the NCgl0580 promoter region, EMSA was conducted by using NonRadioactive EMSA Kits with Biotin-Probes User's Manual VER. 5.11 (Viagene Biotech Inc, Changzhou, China), according to the manufacturer's instruction. The consensus oligonucleotides were BIO-JNZXM-TP (5'-AAA CAGCCAA CTATAGTTAAGTAATA- $3^{\prime}$ ) and BIOJNZXM-BM (5'-TATTACTTAACTATAGTTGGCTGT TT- $\left.3^{\prime}\right)$. The positive control was the nuclear extracts with activated specific TF, and the negative control was the nuclear extracts without activated TF.

\section{Supplementary information}

Supplementary information accompanies this paper at https://doi. org/10.1186/s12934-020-01374-5.

Additional file 1. Additional tables and figures.

\section{Abbreviations}

C. glutamicum: C. glutamicum; SSAAI: C. glutamicum $\triangle$ SSAAI; EGFP: Enhanced green fluorescent protein; EMSA: Electrophoretic mobility shift assays; DMT: Drug/metabolite transporter superfamily; Thr-Thr: L-Threonine dipeptides; Cys-Cys: L-Cysteine dipeptides; Ala-Ala: L-Alanine dipeptides; Val-Val: L-Valine dipeptides; LTTRs: LysR-type transcriptional regulators family; Yp/x: Yield of L-serine to biomass; PSP: Phosphoserine phosphatase; LB: Lysogeny broth; ARTP: Atmospheric and room temperature plasma.

\section{Authors' contributions}

$X M, Y J G$, and ZWC conceived and designed the experiments; XMZ led the working of the experiments; $Y J G$ and ZWC performed the experiments; $X M Z$, GQX, and XJZ analyzed the data; XMZ, YJG, and ZWC wrote the manuscript; and JSS, MK, and ZHX gave suggestions for the experiments and revised the manuscript. All the authors read and approved the final manuscript.

\section{Funding}

This work was financially supported by the National Key Research and Development Program of China (2018YFA0901400), National Natural Science Foundation of China (No. 31600044), Program of National First-class Discipline Program of Light Industry Technology and Engineering (LITE2018-11), Program of Introducing Talents of Discipline to Universities (No. 111-2-06), International Joint Research Laboratory for Engineering Synthetic Biosystem for Intelligent Biomanufacturing at Jiangnan University, Top-notch Academic Programs Project of Jiangsu Higher Education Institutions (TAPP), and China Postdoctoral Science Foundation (No. 2018M640452).

\section{Availability of data and materials}

The datasets used and analyzed in this study are available from the corresponding author on request.

\section{Ethics approval and consent to participate}

Not applicable.

\section{Consent for publication}

Not applicable.

\section{Competing interests}

The authors declare that they have no competing interests.

\section{Author details}

${ }^{1}$ Laboratory of Pharmaceutical Engineering, School of Pharmaceutics Science, Jiangnan University, Wuxi, People's Republic of China. ${ }^{2}$ National Engineering Laboratory for Cereal Fermentation Technology, Jiangnan University, Wuxi, People's Republic of China. ${ }^{3}$ The Key Laboratory of Industrial Biotechnology, Ministry of Education, School of Biotechnology, Jiangnan University, Wuxi, People's Republic of China. ${ }^{4}$ Department of Chemical and Biological Engineering, Rensselaer Polytechnic Institute, Troy, NY, USA. ${ }^{5}$ Department of Biological Sciences, Rensselaer Polytechnic Institute, Troy, NY, USA.

Received: 9 March 2020 Accepted: 25 May 2020

Published online: 29 May 2020

\section{References}

1. Zhang X, Xu G, Shi J, Koffas MAG, Xu Z. Microbial production of L-serine from renewable feedstocks. Trends Biotechnol. 2018;36:700-12. 
2. Mundhada H, Seoane JM, Schneider K, Koza A, Christensen HB, Klein T, Phaneuf PV, Herrgard M, Feist AM, Nielsen AT. Increased production of L-serine in Escherichia coil through adaptive laboratory evolution. Metab Eng. 2016;39:141-50.

3. Peters-Wendisch P, Stolz M, Etterich H, Kennerknecht N, Sahm H, Eggeling $\mathrm{L}$. Metabolic engineering of C. glutamicum for L-serine production. Appl Environ Microbiol. 2005;71:7139-44.

4. Stolz M, Peters-Wendisch P, Etterich H, Gerharz T, Faurie R, Sahm H, Fersterra $\mathrm{H}$, Eggeling L. Reduced folate supply as a key to enhanced L-serine production by C. glutamicum. Appl Environ Microbiol. 2007;73:750-5.

5. Zhu Q, Zhang X, Luo Y, Guo W, Xu G, Shi J, Xu Z. L-Serine overproduction with minimization of by-product synthesis by engineered C. glutamicum. Appl Microbiol Biotechnol. 2015;99:1665-73.

6. Xu G, Jin X, Wen G, Dou W, Zhang X, Xu Z. Characterization, modification, and overexpression of 3-phosphoglycerate dehydrogenase in C. glutamicum for enhancing L-serine production. Ann Microbiol. 2015;65:929-35.

7. Jones CM, Hernández Lozada NJ, Pfleger BF. Efflux systems in bacteria and their metabolic engineering applications. Appl Microbiol Biotechnol. 2015;99:9381-93.

8. Eggeling L, Sahm H. New ubiquitous translocators: amino acid export by C. glutamicum and Escherichia coli. Arch Microbiol. 2003;180:155-60.

9. Dunlop MJ, Dossani ZY, Szmidt HL, Chu HC, Lee TS, Keasling JD, Hadi MZ, Mukhopadhyay A. Engineering microbial biofuel tolerance and export using efflux pumps. Mol Syst Biol. 2011;7:487.

10. Kim S, Ihara K, Katsube S, Hori H, Ando T, Isogai E, Yoneyama H. Characterization of the L-alanine exporter AlaE of Escherichia coli and its potential role in protecting cells from a toxic-level accumulation of L-alanine and its derivatives. Microbiologyopen. 2015;4:632-43.

11. Pérez-García F, Wendisch VF. Transport and metabolic engineering of the cell factory C. glutamicum. FEMS Microbiol Lett. 2018;365:fyn166.

12. Vrljic $M$, Sahm $H$, Eggeling L. A new type of transporter with a new type of cellular function: L-lysine export from C. glutamicum. Mol Microbiol. 1996;22:815-26.

13. Dassler T, Maier T, Winterhalter C, Bock A. Identification of a major facilitator protein from Escherichia coli involved in efflux of metabolites of the cysteine pathway. Mol Microbiol. 2000;36:1101-12.

14. Nakamura J, Hirano S, Ito H, Wachi M. Mutations of the C. glutamicum NCgl1221 gene, encoding a mechanosensitive channel homolog, induce L-glutamic acid production. Appl Environ Microbiol. 2007;73:4491-8.

15. Simic P, Sahm H, Eggeling L. L-threonine export: use of peptides to identify a new translocator from C. glutamicum. J Bacteriol. 2001; 183:5317-5324

16. Lubitz D, Jorge JMP, Pérez-García F, Taniguchi H, Wendisch VF. Roles of export genes cgmA and lysE for the production of $\mathrm{L}$-arginine and $\mathrm{L}$-citrulline by C. glutamicum. Appl Microbiol Biotechnol. 2016;100:8465-74.

17. Schwede T. Protein modeling: what happened to the "Protein Structure Gap"? Structure. 2013;21:1531-40.

18. Simic P, Willuhn J, Sahm H, Eggeling L. Identification of glyA (encoding serine hydroxymethyltransferase) and its use together with the exporter ThrE to increase L-threonine accumulation by C. glutamicum. Appl Environ Microbiol. 2002;68:3321-7.

19. Liu Q, Liang Y, Zhang Y, Shang X, Liu S, Wen J, Wen T. YjeH is a novel exporter of $\mathrm{L}$-methionine and branched-chain amino acids in Escherichia coli. Appl Environ Microbiol. 2015;81:7753-66.

20. Huhn S, Jolkver E, Kramer R, Marin K. Identification of the membrane protein SucE and its role in succinate transport in C. glutamicum. Appl Microbiol Biotechnol. 2011;89:327-35.

21. Maddocks SE, Oyston PCF. Structure and function of the LysRtype transcriptional regulator (LTTR) family proteins. Microbiology. 2008;154:3609-23.

22. Bellmann A, Vrljic M, Patek M, Sahm H, Kramer R, Eggeling L. Expression control and specificity of the basic amino acid exporter LysE of $C$. glutamicum. Microbiology. 2001;147:1765-74.
23. Zhang X, Zhang X, Xu G, Zhang X, Shi J, Xu Z. Integration of ARTP mutagenesis with biosensor-mediated high-throughput screening to improve L-serine yield in C. glutamicum. Appl Microbiol Biotechnol. 2018;102:5939-51.

24. Shang X, Zhang Y, Zhang G, Chai X, Deng A, Liang Y, Wen T. Characterization and molecular mechanism of AroP as an aromatic amino acid and histidine transporter in C. glutamicum. J Bacteriol. 2013;195:5334-42.

25. Kennerknecht N, Sahm H, Yen MR, Pátek M, Saier MH Jr, Eggeling L. Export of L-isoleucine from C. glutamicum: a two-gene-encoded member of a new translocator family. J Bacteriol. 2002;184:3947-56.

26. Wang Y, Cao G, Xu D, Fan L, Wu X, Ni X, Zhao S, Zheng P, Sun J, Ma Y. A novel L-glutamate exporter of C. glutamicum. Appl Environ Microbiol. 2018;84(6):15.

27. Zhao Z, Ding J, Li T, Zhou N, Liu S. The NCgl1 108 (PheP (Cg)) gene encodes a new L-Phe transporter in C. glutamicum. Appl Microbiol Biotechnol. 2011;90:2005-13.

28. Trötschel C, Deutenberg D, Bathe B, Burkovski A, Krämer R. Characterization of methionine export in C. glutamicum. J Bacteriol. 2005;187:3786-94.

29. Yu J, Ge J, Heuveling J, Schneider E, Yang M. Structural basis for substrate specificity of an amino acid ABC transporter. P Natl Acad Sci USA. 2015;112:5243-8.

30. Eggeling L. Exporters for production of amino acids and other small molecules. Adv Biochem Eng Biot. 2016;159:199-225.

31. Mundhada H, Schneider K, Christensen HB, Nielsen AT. Engineering of high yield production of L-serine in Escherichia coli. Biotechnol Bioeng. 2016:113:807-16.

32. Nandineni MR, Gowrishankar J. Evidence for an arginine exporter encoded by yggA ( $\operatorname{argO}$ ) that is regulated by the LysR-type transcriptional regulator ArgP in Escherichia coli. J Bacteriol. 2004;186:3539-46.

33. Marbaniang CN, Gowrishankar J. Transcriptional cross-regulation between Gram-negative and gram-positive bacteria, demonstrated using ArgP-argO of Escherichia coli and LysG-lysE of C. glutamicum. J Bacteriol. 2012;194:5657-66.

34. Binder S, Schendzielorz G, Stäbler N, Krumbach K, Hoffmann K, Bott M, Eggeling L. A high-throughput approach to identify genomic variants of bacterial metabolite producers at the single-cell level. Genome Biol. 2012:13:R40

35. Shah A, Blombach B, Gauttam R, Eikmanns BJ. The RamA regulon: complex regulatory interactions in relation to central metabolism in $C$. glutamicum. Appl Microbiol Biotechnol. 2018;102:5901-10.

36. Rennig M, Mundhada H, Wordofa GG, Gerngross D, WulffT, Worberg A, Nielsen AT, Norholm MHH. Industrializing a bacterial strain for L-serine production through translation initiation optimization. ACS Synth Biol. 2019;8:2347-58.

37. Schafer A, Tauch A, Jager W, Kalinowski J, Thierbach G, Puhler A. Small mobilizable multipurpose cloning vectors derived from the Escherichia coli plasmids pk18 and pk19-selection of defined deletions in the chromosome of C. glutamicum. Gene. 1994;145:69-73.

38. Xu D, Tan Y, Li Y, Wang X. Construction of a novel promoter-probe vector and its application for screening strong promoter for Brevibacterium flavum metabolic engineering. World J Microbiol Biotechnol. 2011;27:961-8.

39. Xu DQ, Tan YZ, Shi F, Wang XY. An improved shuttle vector constructed for metabolic engineering research in C. glutamicum. Plasmid. 2010;64:85-91.

40. Keilhauer C, Eggeling L, Sahm H. Isoleucine synthesis in C. glutamicum: molecular analysis of the ilvB-ilvN-ilvC operon. J Bacteriol. 1993;175:5595-603.

\section{Publisher's Note}

Springer Nature remains neutral with regard to jurisdictional claims in published maps and institutional affiliations. 